\title{
The influence of social-grouping on territorial defense behavior in the black-crested titmouse (Baeolophus atricristatus)
}

\author{
Mirjam J. Borger ${ }^{1,2}$ (D) $\cdot$ Lauren E. Johnson ${ }^{2} \cdot$ Nathaly O. Salazar ${ }^{2} \cdot$ Cameron L. Dreghorn $^{2} \cdot$ Jan Komdeur $^{1} \cdot$ \\ Troy G. Murphy ${ }^{2}$
}

Received: 7 August 2020 / Revised: 23 October 2020 / Accepted: 27 October 2020 / Published online: 3 November 2020

(C) The Author(s) 2020

\begin{abstract}
Status signals have evolved for individuals to avoid energetic and physical costs of resource defense. These signals reflect an individual's competitive ability and therefore influence competitors' decisions on how to invest in a fight. We hypothesized that the response of receivers to status signals will depend on the social context. During territorial defense, group members may provide support to a territory owner by participating in defense. We investigated whether the presence of juveniles - who group together with territorial males - alters the territorial male's attack decisions and level of aggression in the black-crested titmouse (Baeolophus atricristatus). Crest-length in this species functions as status signal. We simultaneously presented two taxidermic male models in a territory: one with an unmanipulated crest and one with a modified shortened crest. Models were presented to males that had resident juveniles cohabiting on their territory, and to males without juveniles. During intrusions, juveniles actively defended against the simulated intruders by approaching and sometimes attacking. The presence of juveniles affected how territorial males responded to the status signals of the intruders: when juveniles were present, males were more likely to first attack the model with the unmanipulated crest (i.e., longer, and more threatening), compared to males residing without juveniles. This suggests that juvenile support alters the risk-taking decision of the territorial male. To our knowledge, this is the first indication that behavioral responses to a status signal depends on the presence of supportive group members.
\end{abstract}

\section{Significance statement}

Status signals can indicate relative quality of animals and can therefore be used to evaluate a competitor when deciding whether or not to fight over resources. The black-crested titmouse has been shown to use its crest length as a status signal during fights over food. In our study, we assessed if this status signal is also used in territorial defense, by conducting an experiment where we presented two taxidermic male models with different crest sizes to a territorial male. We also investigated whether juvenile presence influenced which model was attacked. In trials where juveniles were present, territorial males attacked the longer crested model significantly more often than in trials where territorial males were alone. This suggests that the presence of juveniles, which help the male defend the territory, allows the male to attack the more aggressive-appearing intruder.

Keywords Social support $\cdot$ Status signal $\cdot$ Territory defense $\cdot$ Social environment $\cdot$ Defense behavior

Jan Komdeur and Troy G. Murphy Shared last-authorship

Communicated by S. Pruett-Jones

Mirjam J. Borger

m.j.borger@rug.nl

1 Behavioural and Physiological Ecology, Groningen Institute for Evolutionary Life Sciences, University of Groningen, P.O. Box 11103, 9700 CC Groningen, The Netherlands

2 Department of Biology, Trinity University, One Trinity Place, San Antonio, TX 78212, USA

\section{Introduction}

Defending a geographical area for an extended period of time can be beneficial. Territory owners can secure resources for themselves and their offspring as well as increase mating success (Davies 1978). Consequently, fights over territories are common (Catchpole and Slater 1995; Wood et al. 2017). Physical fighting can be costly, both in terms of time and energy loss and risk of injury. Consequently, mechanisms have evolved that allow potential competitors to estimate the probability of winning a fight before it is initiated. One of 
these mechanisms is the use of status signals (Rohwer 1975). These signals communicate fighting ability by linking signal expression to individual aggression (often linked to testosterone; Evans et al. 2000; Bókony et al. 2008; McGlothlin et al. 2008; Pham et al. 2014; but see Wingfield et al. 2006) or phenotypic condition (Geist 1966; Haley et al. 1994). Status signals were first noted in studies by Rohwer (1975, 1977), where Harris's sparrows (Zonotrichia querula) with larger chest badges were avoided during agonistic interactions by those with smaller status signals. There has since been many advances in the theoretical framework to understand these signals (Diep and Westneat 2013), and there is compelling evidence that status signals are used during defense of various resources, including food (Senar and Camerino 1998; Chaine et al. 2013), breeding territories (Pryke and Andersson 2003; Kraaijeveld et al. 2004), and non-breeding territories (Murphy et al. 2009). Although status signals have been well studied in birds (Nakagawa et al. 2007), these signals can be found across taxa, including reptiles (throat color in tree lizards, Urosaurus ornatus; Thompson and Moore 1991), fish (spots in grayling fish, Thymallus thymallus, Penteriani et al. 2015), and insects (face markings in paper wasps, Polistes dominula, Tibbetts and Dale 2004).

Although much research has focused on advantages to the signaler within a communication network, it is important to also consider the receiver's response to a signal (Searcy and Nowicki 2005) - as the response to a signal may vary depending on the context in which that signal is displayed. Benefits of responding to a signal can depend on multiple factors, both social and environmental (Gill and Wolf 1975; Carpenter 1987; Grant et al. 2002; Johnson et al. 2004; Golabek et al. 2012; Queller and Murphy 2017). It is clear that individuals benefit through modifying their aggression based on social context (Clutton-Brock 1988). For example, investment into aggression can be altered in response to condition of the competitors or size asymmetry (López and Martín 2001; Reichert and Gerhardt 2011), as well as the value each competitor places on the defended resource (Enquist and Leimar 1987). However, little is known about context dependence of receiver response to status signals. Some evidence suggests that receivers do show the ability to respond to status signals differently between social contexts. In a study on the black-crested titmouse (Baeolophus atricristatus), Queller and Murphy (2017) found that status signals function to mediate competition for food, but only during the time of the year when competition for food is extreme. Also, when artificially food competition was increased, status signals were used to mediate competition while this was not the case during the control treatment. Other examples include less aggression towards neighbors versus strangers while counter singing (Temeles 1994), and responding to visual status signals when first encountering an unfamiliar individual, but not responding when encountering a familiar individual (Vedder et al. 2010; Chaine et al. 2018). As such, it is important to consider how the social environment may affect how receivers respond to a status signal.

Among highly social species, aggressive strategies may depend on group-member cooperation, especially during defense (Scott 1980; Scheiber et al. 2005; Kingma et al. 2014). For example, if a group can confront an intruder, together they may exhibit an effective and less risky defense than those who defend the territory alone (Weatherhead 1989). Additionally, investment in aggression by other group members might allow a focal individual to reduce its own investment (Johnstone 2011). Such joint-defense is likely a major benefit of group living (Krause and Ruxton 2002), and auxiliary group members may be "paying to stay" by helping with territory defense (Gaston 1978; Taborsky 1984, 1985). Such group-mediated defense is seen in cooperatively breeding cichlids (Neolamprologus $s p$.), where juveniles help with territory defense (Heg et al. 2005) and decrease the defense efforts of the breeding pair (Jungwirth et al. 2015). Additionally, juveniles in cooperatively breeding woodpeckers (Melanerpes formicivorus) assist in territory defense (Mumme and de Queiroz 1985); however, this did not decrease the defense effort of the breeding pair.

Here, we investigate whether the aggressive response of territorial male black-crested titmouse is affected by the presence or absence of juveniles residing on the territory. Juveniles in this species are unusual among songbirds because they reside for up to 7 months, post-breeding season, in groups composed of two territorial adults and up to six juveniles (TGM, unpublished data). We focus on the large crest of the male titmouse, which previous work has indicated a status signal function: longer crested individuals were found to beat those with shorter crests during competition for food (Queller and Murphy 2017). We hypothesize that the presence of juveniles on a male's territory will provide a benefit to the male. Juveniles may, for example, provide active social support by participating in physically defending against intruders. Because we expect that juvenile presence is beneficial, we also predict that as a result of juvenile support, territorial males will be willing to take greater risks during aggressive interactions when juveniles are providing support on their territory, compared to when there are no juveniles present. Alternatively, juveniles may provide no benefit to the territorial male, in which case we do not expect juveniles to participate in territory defense, nor do we expect the risk taking of territorial males to depend on the presence of juveniles.

We address these hypotheses by conducting a simulated territorial intrusion experiment on territories either where juveniles were present on the territory or where they were absent. We used taxidermic male models (hereafter "models") with different crest-lengths to assess whether territorial males are more likely to take risks and attack the more threatening 
(i.e., larger crested) intruder in the presence of juveniles. This study explicitly considers the social environment in which a signal is given and received. To our knowledge, this is novel because the combined effects of the social environment and status signals on the expression of territorial behaviors are complex and generally not well understood.

\section{Methods}

\section{Study species and fieldwork}

The black-crested titmouse is a socially monogamous passerine inhabiting Texas, Oklahoma (USA), and Mexico (Patten and Smith-Patten 2008). The species is not a cooperative breeder, although anecdotes suggest that cooperative breeding may rarely occur. Males are highly territorial, defending territories during the breeding season and then defending expanded home ranges throughout the remainder of the year (Brawn and Samson 1983). Juveniles in this species can reside for up to 7 months, post-breeding season, in groups composed of juveniles and two territorial adults (TGM pers. obs.). Groups vary in size from two adults with zero to six juveniles (TGM, unpublished data). Fieldwork took place from May 18th to July 12 th 2018, which was shortly after the end of the breeding season, during the period when juveniles reside on the adults' territory. The study was done at a field site near San Antonio, TX, USA $\left(29^{\circ} 41^{\prime} 15 \mathrm{~N}, 98^{\circ} 19^{\prime} 49 \mathrm{~W}\right)$. We trapped the adult male after each trial of our experiment using mist nets and a model titmouse as a decoy. We did not catch the males before the experiment to avoid altering their territorial behavior. Because focal individuals were caught and ringed after our trials, all observations were blind.

We measured tarsus and bill length (using calipers to the nearest $0.01 \mathrm{~mm}$ ), wing (using stop ruler to the nearest 0.5 $\mathrm{mm}$ ), crest length (using a standardized picture of the crest, including a ruler, and software ImageJ) (Rasband 19972018), and mass (using digital scale to the nearest $0.1 \mathrm{~g}$ ), and we visually assessed crest wear, color of the crest, and the color of the base of the bill. Crest color was measured on a scale of zero to three, with score zero equivalent to gray, score one to brownish black, score two to intermediate black, and score three to dark black. The color score for each individual was assessed by holding the bird's crest against a black standard. Crest wear was also assessed on a scale from zero to three, with score zero equivalent to no wear, and score three equivalent to extreme wear. Crest and the color of the base of the bill color were used together to assess the age of individuals: Juveniles have a gray crest and a gray proximal lower mandible, while adult birds have a black crest and a black lower mandible (TGM pers. obs.). For each individual, we took a picture of the flattened crest to obtain a standardized measure of the crest length, and a small blood sample from the alar vein $(20 \mu \mathrm{l})$ for molecular sexing (see below). Each individual was ringed with a unique combination of three colorbands and a metal band with a unique number.

\section{Simulated territorial intrusion experiment}

To study the effect of intruder crest size and the presence of juveniles on male territorial behavior, we conducted an experiment wherein we simultaneously presented two male taxidermic models on a defended territory. The models were placed 1 $\mathrm{m}$ above the ground and $2 \mathrm{~m}$ apart, as developed by Korsten et al. (2007). This allowed us to distinguish which model the male territory owner investigated or attacked. We used a simultaneous presentation of the models instead of a sequential setup, because it allowed territorial individuals to actively compare the perceived threat posed by two rivals (following Korsten et al. 2007). Simultaneous intrusion experiments have often been used to test aggressiveness towards intruders (Rémy et al. 2010; Midamegbe et al. 2011; Coady and Dawson 2013). Our experimental setup was as follows: one taxidermic model had an unmanipulated crest length, while the other had a modified shortened crest length (for crest size manipulation, see below). Crests were not lengthened as an additional experimental treatment due to difficulty of creating realistic artificially long crests. We did not investigate the response of female titmice, because females do not participate significantly in territorial defense (MJB and TGM pers. obs.).

A speaker was placed underneath and in between the two models, and a sequence of titmouse songs was played to attract the territory owner. The songs were recorded in an area $>$ $50 \mathrm{~km}$ away, thus ensuring that the singer would not be recognized and would be perceived as an intruding male (for experimental setup, see Fig. 1). All observations were from a portable blind placed ca. $30 \mathrm{~m}$ from the experimental setup. Behavior was observed through binoculars by two researchers who verbally described what they observed, while a third researcher recorded their observations. MJB observed during all trials and was assisted in observing by either LEJ, NOS, or CLD. After a defending titmouse approached within $30 \mathrm{~m}$ of the experimental setup, the volume was reduced to halfvolume to resemble the natural amplitude of the song. The same sequence of songs was played throughout the experiment. Experimental trials were conducted for $30 \mathrm{~min}$, or until the adult male attacked a model. If juveniles were first to attack the model(s), the trial continued until the adult attacked.

In total, we used 12 taxidermic models of adult males. Six of the 12 models were chosen randomly to have an experimentally shortened crest, while the other six kept their natural crest length. Shortening of the crest occurred by trimming approximately $5 \mathrm{~mm}$ off the crest with scissors, thus placing the crest of the shortened crest models in the lower $11 \%$ distribution of crest sizes in our population (based on all individuals captured, $n=19$ ). Trimming was done in a way to 
Fig. 1 a A black-crested titmouse with its distinct black crest (photo by Mirjam J. Borger). b The experimental setup of the simulated territorial intrusion experiment

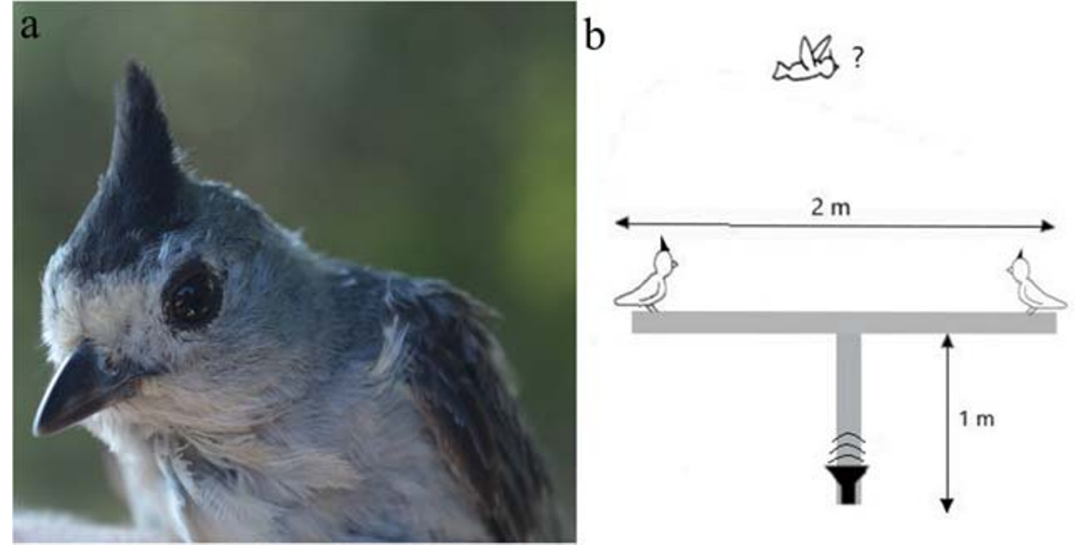

preserve the pointed shape of the crest (i.e., shortened crest models did not have "flat-tops") and crest color was consistently black on the whole crest, so this also did not change by trimming. Over the course of the experiment, each of the models with shortened crests was paired with one of the models with an unmanipulated crest; however, because two of the 12 models were of substantially larger body size compared to the other models, these two were paired together and used in only one experimental presentation. We had 26 possible combinations of models. We ran 25 successful trials where we elicited territorial response, each performed on a separate territory. The models placed in the two treatments did not differ in crest length before shortening (mean $\pm \mathrm{SD}$ of shortened crest models $=31.6 \pm 1.57, n=6$, mean \pm SD of unmanipulated crest models $=31.5 \pm 1.34, n=6$; $t$ test, $t$ value $=-0.16, \mathrm{df}=10, p=0.88)$. There was natural variation in the crest length of the taxidermic models; however, the shortened crests were significantly shorter than the unmanipulated crests (mean $\pm \mathrm{SD}$ of shortened crest models $=25.6 \pm 0.87 \mathrm{~mm}, n=$ 6 , mean \pm SD of unmanipulated crest models $=31.5 \pm 1.34, n$ $=6 ; t$ test, $t$ value $=9.03, \mathrm{df}=10, p<0.001)$, and both treatments were still in the range of natural crest sizes of males caught in our population (range 24.2-34.3 mm, mean $\pm \mathrm{SD}=$ $29.6 \pm 2.26)$. We found that there was a negative correlation between crest length and crest angle (how raised the crest was) in the taxidermic models. However, we studied only crest length because this trait had already been suggested to function as a status signal in previous work (Queller and Murphy 2017).

To understand if territory owners preferentially attacked shorter versus longer crested models, we recorded which arm of the horizontal perch the territorial male first landed (i.e., near the shortened- or unmanipulated-crest model), and we recorded which model was first attacked. We ended trials when the adult male territory owner attacked a model. To investigate whether territory owners with longer crests attacked the intruders more quickly than territorial males with shorter crested males, we measured the latency between the time when the adult male entered a $7-\mathrm{m}$ range around the setup, and two variables: when the male landed on the experimental setup, and when the male attacked a model. Seven meters was chosen because all activity could readily be seen within this area.

\section{Juvenile presence}

To investigate the effect of juveniles on attack behavior, we determined whether there were juveniles present within $30 \mathrm{~m}$ of the models during each trial. On a few occasions (five trials), a juvenile attacked the model before the adult did so. In these cases, we emerged from the blind to scare off the juvenile (to prevent damage to the models) and then returned to our blind to continue the trial. The trials continued until the adult male attacked a model. Due to the disturbance of chasing away the attacking juvenile, we did not use these trials in analyses for latency of attack by the adult male. We scored the presence or absence of juveniles, because quantifying the number of juveniles was not possible due to dense vegetation and because individuals were not marked individually.

\section{Molecular sexing}

We genetically sexed all captured birds as well as the taxidermic models. Models were confirmed to be males; however, one of the samples did not contain enough DNA to determine the sex. We are confident that this model was a male model because it sang frequently (a male-only trait, TGM personal observation) before it was collected. DNA was extracted from the toepads of the model birds using a sterilized razor blade and Qiagen DNeasy Blood and Tissue kit and the manufactures protocol. DNA was extracted from the blood samples of the focal alive birds using an ammonium acetate method as described in (Richardson et al. 2001). Molecular sex of the birds was assessed using the method of Griffiths et al. (1998) and/or van der Velde et al. (2017). Specifically, PCR reactions were carried out in $10-\mu \mathrm{l}$ volume containing $0.2 \mathrm{mM}$ of each dNTP, $0.5 \mu \mathrm{M}$ of each primer P2 and P8 (Griffiths et al. 1998) or $2602 \mathrm{~F}$ and 2669R (van der Velde et al. 2017), $10 \mathrm{mM}$ Tris- 
$\mathrm{HCl}, 50 \mathrm{mM} \mathrm{KCl}, 3.0 \mathrm{mM} \mathrm{MgCl} 2,0.25 \mathrm{U}$ Taq DNA polymerase (Roche Diagnostics GmbH, Mannheim, Germany), and 2- $\mu$ l DNA template. The PCR-program consisted of 1 min: $94^{\circ} \mathrm{C}, 35$ cycles of $94{ }^{\circ} \mathrm{C}$ for $30 \mathrm{~s}, 50^{\circ} \mathrm{C}$ for $60 \mathrm{~s}$ (primers $\mathrm{P} 2$ and P8), or $60^{\circ} \mathrm{C}$ for $60 \mathrm{~s}$ (primers $2602 \mathrm{~F}$ and 2669R), and $72{ }^{\circ} \mathrm{C}$ for $45 \mathrm{~s}$, followed by $72{ }^{\circ} \mathrm{C}$ for two min. PCR products were separated on a $2 \%$ agarose gel by electrophoresis and visualized by ethidium bromide staining.

\section{Statistical analyses}

For statistical analyses, R 3.4.1 (R Core Team 2018) was used, with the packages ggplot2 and ggpubr to produce graphs. Because body size did not significantly correlate with crest length (see below), we used raw measures of crest length throughout the study. A $\chi^{2}$ test was used to analyze whether focal adult males preferentially attacked either the unmanipulated or shortened crest model. To analyze the effect of juvenile presence on male choice, we used a generalized linear model with a binomial logistic distribution because our sample sizes were not large enough in each category for a $\chi^{2}$ test or a binomial test. Because sample sizes were limited, differences between the territorial males that were and those that were not associated with juveniles were tested post hoc with $t$ tests instead of adding these factors in the model. We captured and measured morphometrics of 21 out of 25 focal males after the experimental trials; however, we were only able to measure crest length properly in 19 individuals. Crest length was not correlated with any body size measure $(n=$ 19 , linear models, body mass estimate $=-0.51, p=0.38$; tarsus estimate $=-0.94, p=0.32$; bill estimate $=-1.76$, $p=0.43$; wing estimate $=-0.05, p=0.85$ ); therefore, it was not necessary to control for body size in our analyses. In all cases, the territorial male approached or attacked a model. In one of the trials, the territorial male landed on the experimental setup, but did not attack a model, and so sample sizes differ between analysis on landing and attacking.

\section{Results}

\section{Presence and territoriality of juveniles}

Juveniles were present on the male's territory in 12 of the 25 territories during simulated territorial intrusion experiments. Juveniles were observed to be highly agitated during the experimental intrusions, vocalizing with the aggressive chatter call, and approaching and swooping towards the models, and in some cases attacking a model $(n=5)$.

\section{Effect of presence of juveniles on the territorial male's aggressive decisions}

\section{Effect on pre-fight behavior}

The presence of juveniles did not influence the territorial male's latency from entering the 7-m range around the experimental setup and landing on the experimental setup (slope $=$ 1.91, $\left.n=22, r^{2}=0.01, p=0.64\right)$ nor the latency to attack (slope $=0.22, n=21, r^{2}=0.0002, p=0.96$, Fig. 2).

\section{Effect on investigative behavior (i.e., landing near a model)}

The presence or absence of juveniles did not influence the preference to land on the experimental setup near one model versus the other (generalized linear model with binomial logit distribution, slope $=1.16, n=25, p=$ 0.16 , Fig. 3a). When excluding the influence of the presence or absence of juveniles from the analysis (i.e., removing the interaction effect), the territorial males did not show a preference to land on the experimental setup near one model versus the other (landed near unmanipulated crest model, $n=13$; landed near shortened crested model, $\left.n=12, \chi^{2}=0.04, p=0.84\right)$.

\section{Effect on attack behavior}

In contrast to pre-fight and investigatory behavior, male territory owners exhibited different aggressive behaviors when in the presence versus the absence of juveniles: focal territorial males were more than twice as likely to attack the unmanipulated (longer) crest model compared to the shortened crest model when juveniles were present (generalized linear model with binomial logit distribution, slope $=1.79, n=24$, $p=0.048$, Fig. $3 b$ ). When excluding the influence of the presence or absence of juveniles from the analysis (i.e., removing the interaction effect), the territorial male's aggressive territorial decision was not influenced by crest size of the models (first attack towards unmanipulated crest model, $n=$ 11; first attack towards small crested model, $n=13, \chi^{2}=0.17$, $p=0.68)$.

\section{Effect of behavior of juveniles on the territorial male's aggressive decisions}

In five cases, juveniles attacked a model before the territorial male did so. However, a juvenile attacking first did not influence which model the male territory owner attacked first (generalized linear model with binomial logit distribution, estimate $=-0.51, n=12, p=0.68$, Fig. 4). 


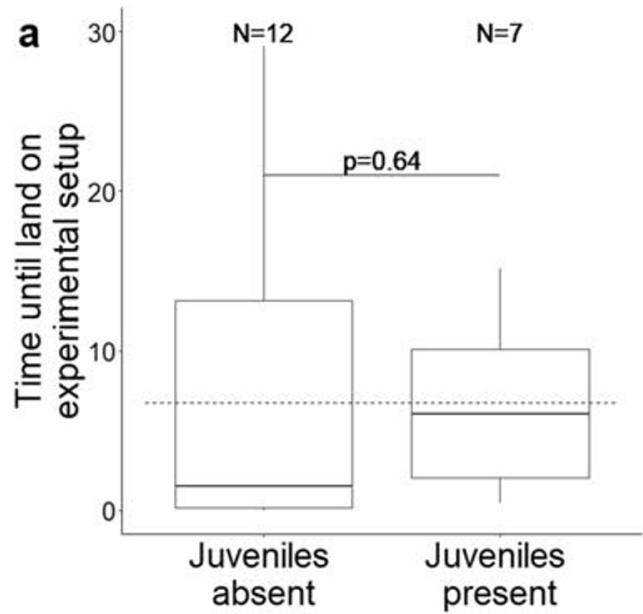

Fig. 2 The influence of juvenile presence on male black-crested titmouse latency. a The effect of juvenile presence on time until the adult male landed on experimental setup after entering a 7-m range around the experimental setup. $\mathbf{b}$ The effect of juveniles on time until the adult male attacked a taxidermic model after entering a 7-m range around the

\section{Territorial male's morphometrics in relation to agonistic behavior}

Crest length was measured for 19 territorial males. Crest length of a territorial male was not related to the likelihood of having juveniles on his territory $(t$ test, mean focal male crest length of males associating with juveniles $30.0 \mathrm{~mm} \pm 0.3$ (SE), $n=7$, without juveniles $29.5 \mathrm{~mm} \pm 0.8$ (SE), $n=12 ; t$ test, $t=-0.21, \mathrm{df}=17, p=0.84)$. Age classes were known for 21 territorial males. The age-classes of males with and without juveniles present were similar (mean age with juveniles 1.6 years $\pm 0.2(\mathrm{SE}), n=9$, without juveniles 1.4 years $\pm 0.1, n=$

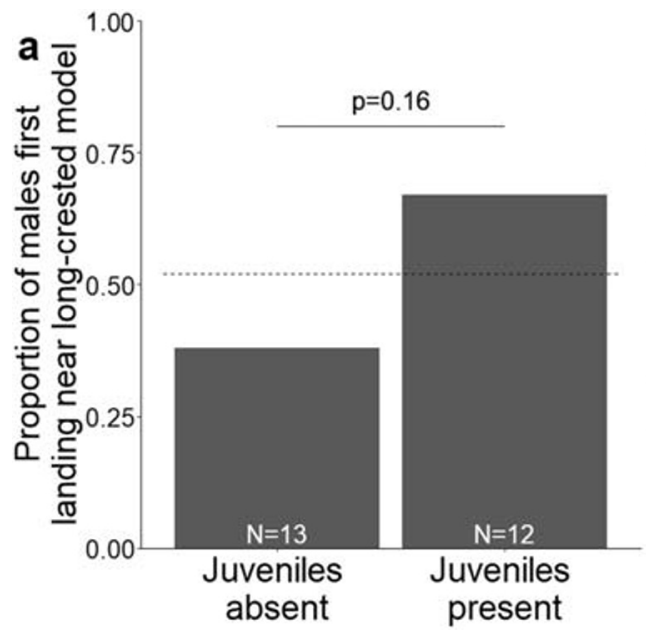

Fig. 3 The influence of juvenile presence on the territorial decisions of adult male black-crested titmice. a The effect of juvenile presence on where the adult male first landed on the experimental setup. b The effect of juvenile presence on which taxidermic model was first attacked. In both "a" and "b", the value 0.5 on the $Y$-axis represents that neither model

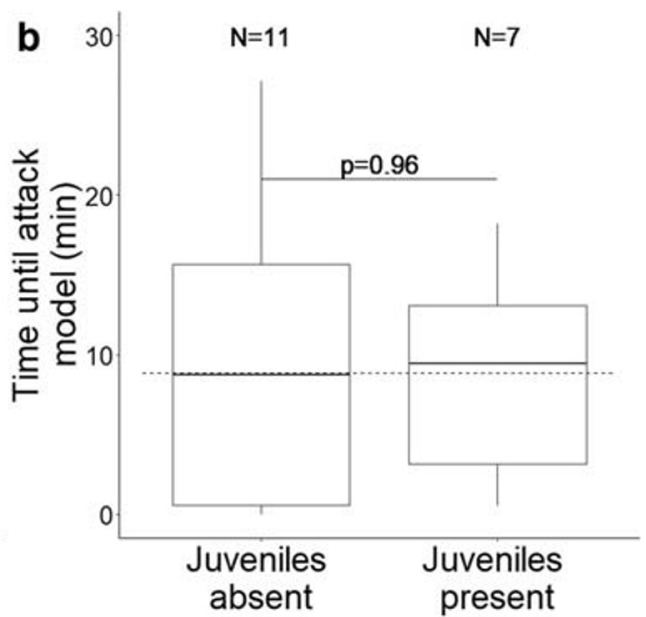

experimental setup. The thick black lines represent the medians, the boxes represent the interquartile range, and the whiskers show the outer $25 \%$ and $75 \%$ of the data. The dotted lines show the means of both groups together

12, $t=-0.61, \mathrm{df}=19, p=0.55)$. The crest length of the territorial male did not predict the latency between entering the 7-m range and landing on the experimental setup (linear model, slope $=-0.40, n=15, r^{2}=0.01, p=0.68$ ), nor the latency between entering the $7-\mathrm{m}$ range and attacking the model (linear model, slope $=1.13, n=14, r^{2}=0.10, p=$ 0.28 , Fig. 5a). Crest length of the territorial male did not predict which side of the experimental setup the territorial male first landed (estimate $=0.35, n=19, p=0.18$, mean crest length males first landing near unmanipulated model $( \pm \mathrm{SE})$, $30.3 \pm 0.6$, mean crest length males first landing near manipulated model, $28.9 \pm 0.8$, Fig. 5b). Furthermore, crest length of

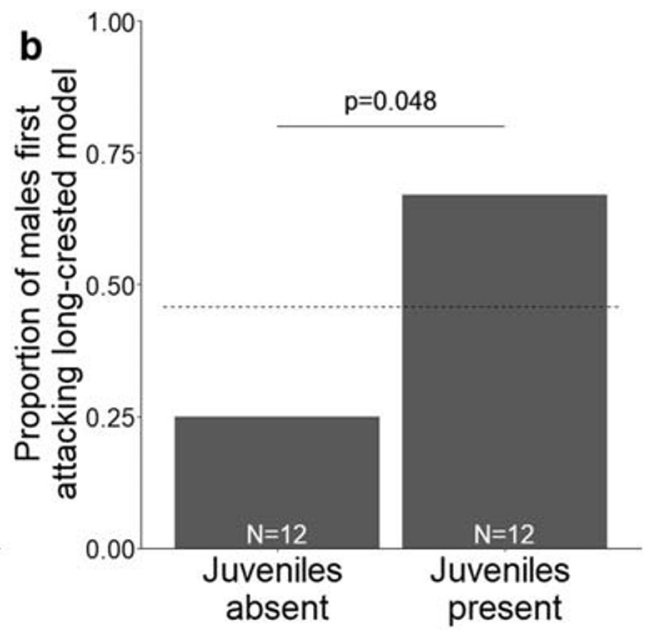

was more likely to be attacked/approached. 0 represents complete bias towards shortest crest models and 1 represents a complete bias for the model with the longest crest. The dotted lines show the means of both groups together. $\mathrm{N}$ denotes sample sizes in both graphs 


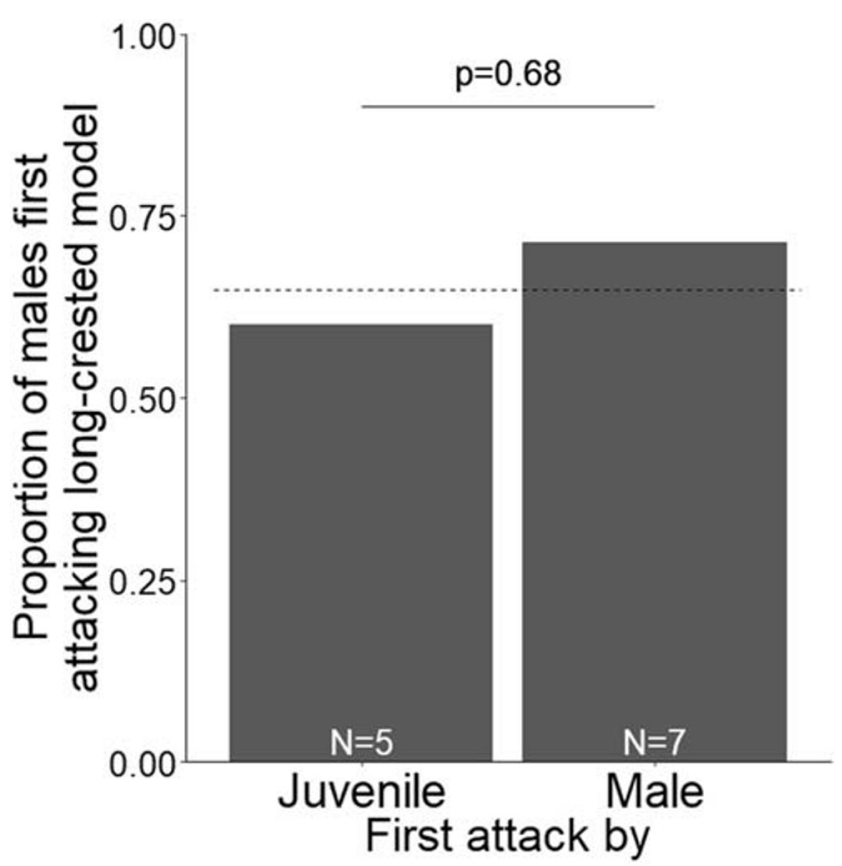

Fig. 4 The influence of juvenile actions on the behavior of the male black-crested titmouse territory owner. In five cases, juveniles attacked a model before the territorial male did so. This did not have an effect on which model the territorial male attacked first

the territorial male did not predict which model was first attacked (slope $=-0.02, n=18, p=0.93$, mean crest length of males first attacking unmanipulated model, $29.80 \pm 0.56$, mean crest length of males first attacking manipulated models, $29.88 \pm 0.80$, Fig. 5c).

We additionally investigated whether body morphometrics of the territorial male influenced which side he landed on first, and which model he first attacked. Because three body morphometrics were correlated (tarsus, bill, and crest wear were correlated with each other, tarsus and bill slope $=0.22, p=$ 0.015 ; tarsus and crest wear slope $=-0.32, p=0.036$; bill and crest wear slope $=-0.19, p=0.001$, for all other correlations $p$ $>0.10$ ), we chose to only test tarsus out of these, since this trait showed most variation. Wing length, tarsus length, mass, and crest color of the territory owner were not significantly related to these responses $(p>0.21)$, nor were these body morphometrics related to latency of attack after entering the $7-\mathrm{m}$ range (in all analyses, $p>0.11$ ), though there was a trend for larger males (based on tarsus length) to exhibit a shorter latency to attack $(p=0.073)$.

\section{Discussion}

It may be beneficial for an individual to allow others to join its social group, as group members can contribute to territorial defense and reduce the need of original group members to participate in risky defense behaviors (Johnstone 2011; Jungwirth et al. 2015). In black-crested titmice, multiple juveniles spend up to 7 months on a territory with an adult pair, although some territories lack such juvenile groups (MJB and TGM pers. obs.). Using simulated territorial intrusions, we showed that resident juvenile black-crested titmice are highly involved in actively defending a male's territory, and that their presence affects the aggressive decisions of the territorial male. The presence of these resident juveniles was significantly associated with the territorial male's decision to first attack the more threatening, larger crested, of the simulated territorial intruders. The decision of the territorial male may reflect that he faces fewer costs of territory defense when he is assisted by juveniles - and so takes greater risks by attacking the more threatening territorial intruder with the larger status signal. However, the actual involvement of juveniles in attacking an intruder does not appear to influence his decision, suggesting that the mere presence of juveniles is important for a male's risk-taking decision, instead of the direct actions of the

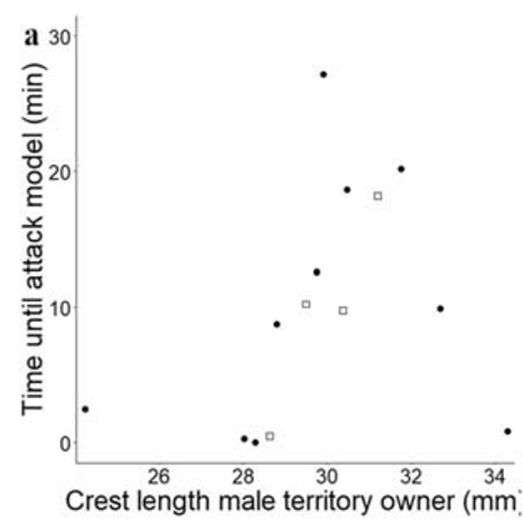

Fig. 5 The influence of crest length of male black-crested titmouse territory owner on his agonistic behavior. a The effect of crest length on the time until attacking a taxidermic model after entering a 7-m range around the experimental setup. Open squares indicate trials where juveniles were present and closed dots represent trials where juveniles were absent. b
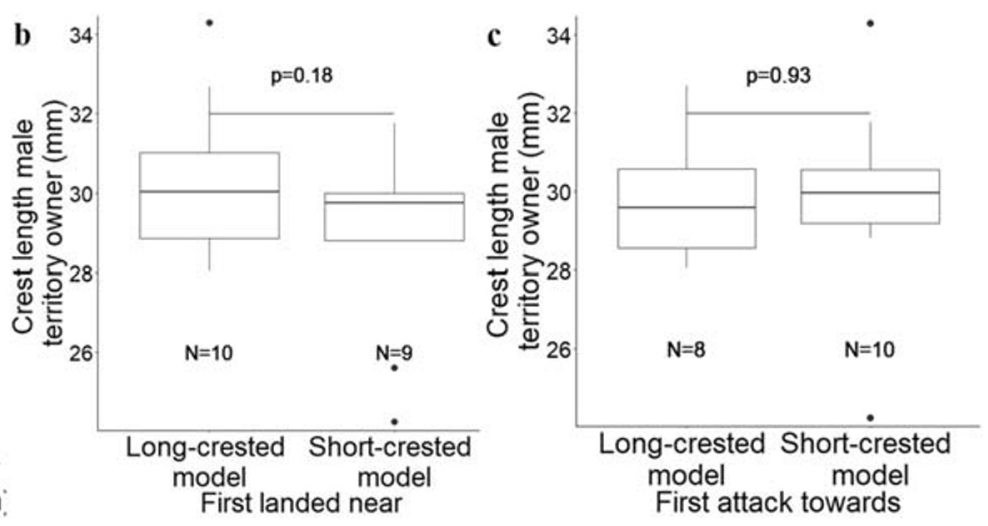

The effect of crest length on where the adult male first landed on the experimental setup. $\mathbf{c}$ The effect of crest length on the decision of which model was first attacked. The line in the boxplot shows the median. The box represents the interquartile range, the whiskers the outer $25 \%$ and $75 \%$ of the data, and the dots represent outliers 
juveniles. In any case, the presence of juveniles is an important part of the social environment, influencing territorial defense strategies in this species.

The presence of juveniles may influence the territory defense decisions of the resident male because they provide active social support by participating in territory defense (Horrocks and Hunte 1983; Pereira 1992) or because they provide passive social support (for example vigilance), wherein their presence provides a stress-reducing effect on the adult (Frigerio et al. 2003; Weiss and Kotrschal 2004; Scheiber et al. 2005). Reduced stress can be beneficial in the long term, as it may increase health and survival (Dickens and Romero 2016). The supportive role provided by these juveniles may explain why they are allowed to remain on the adults' territory for up to 7 months. Our results parallel other cases where juveniles help territory owners in defense. Most of these examples come from cooperative breeders (Koenig and Dickinson 2004; Koenig and Dickinson 2016); however, in another non-cooperatively breeding species, the pied wagtail (Motacilla alba), floater juveniles are sometimes allowed on the territory for a short period if they help defend the territory (Davies and Houston 1981). Our study adds to a short list of cases where juveniles appear to provide support to adults in a non-cooperatively breeding species.

When territory owners allow supportive juveniles to reside on their territory, one potential outcome is that the territorial males would reduce their own aggressive response because juvenile participation reduces their own need to invest. We did not find that male territory owners showed greater latency to attack the models in the presence of juveniles compared to absence of juveniles. However, in five of the 12 trials where juveniles were present, the juveniles attacked a model before the adult. It might be the case, in a naturalistic context (with live intruders) that defense by juveniles would have been sufficient to drive away the intruders, lowering the need of the adult male to attack. In our study, the adult male may have only invested in territorial defense when he detected that the juveniles were not effective in driving away the taxidermicmodel intruders. Future research on this topic will need to focus on the effectiveness of group defense versus lone-male defense

We offer some alternative, however not mutually exclusive, interpretations of our results. First, it is possible that adult males were more likely to attack the more threatening intruder in the presence of juveniles because the juveniles are offspring of the adult male, and defense of territorial resources for use by kin may motivate greater risk taking. However, our preliminary results from genetic parentage analysis indicate that social groups often are composed, at least in part, of juveniles that are unrelated to the male. Some of this variation in relatedness may be due to extra-pair paternity; however, our results parallel work on the sister species, the tufted titmouse (Baelophus bicolor), where the extra-pair paternity rate is low (8.8\%, (Pravosudova et al. 2002)), yet juveniles were related to the pair in only $42 \%$ of territories (Pravosudova et al. 1999). Future work will need to test whether the presence/absence of related juveniles influences a male's territorial decisions. A second alternative is that males could be teaching juveniles how to defend a territory against conspecifics, similar as in the Siberian jay (Perisoreus infaustus) where juveniles are taught by observing knowledgeable adults to recognize predators (Griesser and Suzuki 2017). However, it is unclear as to why males would make the optimal defense decision of attacking the more threatening male in the presence of juveniles, and then behave sub-optimally in their absence. Furthermore, this explanation seems unlikely because ten out of the fifteen juveniles that we captured were females, and adult females do not go on to substantially participate in territory defense. As a third alternative explanation, adults could change their strategy based on their social environment. For example, solitary males may first attack the intruder which is easier to expel (short crested) in order to quickly reduce the number of intruders, while males in groups may first attack the more threatening intruder (long crested) - as is expected by signaling theory (see Murphy et al. 2009). A fourth alternative is that juveniles, through their participation in territory defense, may provide males an opportunity to defend a higher quality or larger territory, which would increase the resource value of the territory. Such an increase in value may motivate the adult territorial male to invest in riskier territorial behaviors, but it remains unclear why juveniles would tend to group with some adults over others - unless those males that gained juvenile support already had larger or higher quality territories. As an extension, a fifth alternative is that the presence of juveniles may result from the male's defense tactics: juveniles may preferentially join males with larger or higher quality territories, and territorial males on those better territories may be the ones who employ riskier defense tactics. However, in our population, we did not see a difference in crest length between the males with and without juveniles, suggesting that males with larger status signals - which have greater competitive success (see Queller and Murphy 2017) — are not more likely to attract juveniles to their territory. Future work should compare territory quality and the presence/absence of juveniles with risk taking during defense.

We also note that we expect group size to be of major importance when adult males weigh alternative defense tactics. Larger groups are likely to be better in territory defense and an increase in group size has been shown to improve reproductive success in cooperatively breeding groups (Balshine et al. 2001). Future work should asses how group size influences the risk-taking behavior of the adult male titmice.

Previous work on status signals indicates that simulated territorial intrusions can be affected by the way in which simulated intruders are presented. Alonso-Alvarez et al. (2004) 
demonstrated a positive status signal function to head plumage in the blue tit (Cyanistes caeruleus), yet Korsten et al. (2007) found a lack of status signal function to the same feather patch in the same species (although in a different population), suggesting that receivers may not always respond to a status signal in the same manner. However, these experiments were carried out using different methodologies. AlonsoAlvarez et al. (2004) presented taxidermic models as lone invaders, one at a time, whereas Korsten et al. (2007) employed a methodology parallel to our own - using a simultaneous presentation of two taxidermic models differing in status signal expression. When models are presented simultaneously, we suspect that the presence of two same-sex intruders may represent a greater threat to the territorial male's prospect of maintaining its territorial tenure, therefore changing the strategy of the male. However, in the presence of social support, territorial titmice appear to alter their strategy of defense and discriminate against the more threatening intruder.

\section{Conclusions and recommendations for future research}

The presence of juveniles was significantly associated with territorial males choosing to first attack the model signaling the highest threat. This suggests that juveniles provide support to the territorial male and that there is an important role of the social environment on decisions of territorial behavior. We recommend that future research investigates the roles that group members take in other tasks, such as defending against predators - as this will further elucidate the benefits to a territorial male for allowing a group to reside on his territory. We also recommend expanded study of the benefits gained by associating with juveniles, such as lowering stress on the territorial male, and whether group defense can lead to increased territory size. We also recommend focusing on the decision that juveniles make in choosing which territory they reside upon. Across taxa, juveniles are known to remain on their natal territory for some period after reaching self-sufficiency. As such, future work should test the role that resident juveniles play in territorial defense, even among species where the juveniles are present for only a short period, as is seen after fledging in many songbirds.

Acknowledgments We thank Sjouke Anne Kingma, Martijn Hammers, Brittney Ivanov, and Michele Johnson for valuable feedback on the research. We thank Marco van der Velde for molecular sexing. We thank Bat Conservation International and the Nature Conservancy for access to their properties, and we extend our gratitude to Fran Hutchins for generously supporting our research. We gratefully thank our anonymous reviewers for their useful suggestions to improve our manuscript.
Availability of data and material All data are stored online on the dryad of GELIFES, University of Groningen, that is accessible via https://hdl. handle.net/10411/2WBW64.

Funding This research was supported by a grant from the Nikolaas Mulerius Foundation (University of Groningen) to JK, MJB, and TGM, a grant from The Groningen University Fund and the Marco Polo fund (University of Groningen) to MJB, and support was provided from Trinity University, the Keck Fund, and the Bricker Ecology Fund to TGM.

\section{Compliance with ethical standards}

Conflicts of interest The authors declare that they have no conflict of interest.

Ethics approval Animal use followed USDA and PHS guidelines for the ethical use of vertebrate animals in research. The research protocol was reviewed and approved by Trinity University (011818 TM5). The time that animals were under stress was kept to a minimum during the presentation of a simulated territorial intruder, and during capture and handling.

Informed consent All authors agreed on the content and gave their consent for publishing this manuscript.

Open Access This article is licensed under a Creative Commons Attribution 4.0 International License, which permits use, sharing, adaptation, distribution and reproduction in any medium or format, as long as you give appropriate credit to the original author(s) and the source, provide a link to the Creative Commons licence, and indicate if changes were made. The images or other third party material in this article are included in the article's Creative Commons licence, unless indicated otherwise in a credit line to the material. If material is not included in the article's Creative Commons licence and your intended use is not permitted by statutory regulation or exceeds the permitted use, you will need to obtain permission directly from the copyright holder. To view a copy of this licence, visit http://creativecommons.org/licenses/by/4.0/.

\section{References}

Alonso-Alvarez C, Doutrelant C, Sorci G (2004) Ultraviolet reflectance affects male-male interactions in the blue tit (Parus caeruleus ultramarinus). Behav Ecol 15:805-809

Balshine S, Leach B, Neat F, Reid H, Taborsky M, Werner N (2001) Correlates of group size in a cooperatively breeding cichlid fish (Neolamprologus pulcher). Behav Ecol Sociobiol 50:134-140

Bókony V, Garamszegi LZ, Hirschenhauser K, Liker A (2008) Testosterone and melanin-based black plumage coloration: a comparative study. Behav Ecol Sociobiol 62:1229-1238

Brawn JD, Samson FB (1983) Winter behavior of tufted titmice. Wilson Bull 95:222-232

Carpenter FL (1987) Food abundance and territoriality: to defend or not to defend? Am Zool 27:387-399

Catchpole CK, Slater PJB (1995) Bird song. Cambridge University Press, Cambridge

Chaine AS, Roth AM, Shizuka D, Lyon BE (2013) Experimental confirmation that avian plumage traits function as multiple status signals in winter contests. Anim Behav 86:409-415 
Chaine AS, Shizuka D, Block TA, Zhang L, Lyon BE (2018) Manipulating badges of status only fools strangers. Ecol Lett 21: 1477-1485

Clutton-Brock TH (1988) Reproductive success: studies of individual variation in contrasting breeding systems. University of Chicago Press, Chicago

Coady CD, Dawson RD (2013) Subadult plumage color of female tree swallows (Tachycineta bicolor) reduces conspecific aggression during the breeding season. Wilson J Ornithol 125:348-357

Davies NB (1978) Ecological questions about territorial behaviour. In: Krebs JR, Davies NB (eds) Behavioural ecology: an evolutionary approach, 1st edn. Blackwell Scientific Publications, Oxford, pp $317-350$

Davies NB, Houston AI (1981) Owners and satellites: the economics of territory defence in the pied wagtail, Motacilla alba. J Anim Ecol 50:157-180

Dickens MJ, Romero M (2016) Coping with stress in wild birds - the evolutionary foundations of stress responses. In: Bremner JD (ed) Posttraumatic stress disorder: from neurobiology to treatment. John Wiley \& Sons Inc., Hoboken, pp 145-158

Diep SK, Westneat DF (2013) The integration of function and ontogeny in the evolution of status signals. Behaviour 150:1015-1044

Enquist M, Leimar O (1987) Evolution of fighting behaviour: the effect of variation in resource value. J Theor Biol 127:187-205

Evans MR, Goldsmith AR, Norris SRA (2000) The effects of testosterone on antibody production and plumage coloration in male house sparrows (Passer domesticus). Behav Ecol Sociobiol 47:156-163

Frigerio D, Weiss BM, Dittami J, Kotrschal K (2003) Social allies modulate corticosterone excretion and increase success in agonistic interactions in juvenile hand-raised graylag geese (Anser anser). Can J Zool 81:1746-1754

Gaston AJ (1978) The evolution of group territorial behavior and cooperative breeding. Am Nat 112:1091-1100

Geist V (1966) The evolutionary significance of mountain sheep horns. Evolution 20:558-566

Gill FB, Wolf LL (1975) Economics of feeding territoriality in the golden-winged sunbird. Ecology 56:333-345

Golabek KA, Ridley AR, Radford AN (2012) Food availability affects strength of seasonal territorial behaviour in a cooperatively breeding bird. Anim Behav 83:613-619

Grant JWA, Girard IL, Breau C, Weir LK (2002) Influence of food abundance on competitive aggression in juvenile convict cichlids. Anim Behav 63:323-330

Griesser M, Suzuki TN (2017) Naive juveniles are more likely to become breeders after witnessing predator mobbing. Am Nat 189:58-66

Griffiths R, Double MC, Orr K, Dawson RJG (1998) A DNA test to sex most birds. Mol Ecol 7:1071-1075

Haley MP, Deutsch CJ, Le Boeuf B (1994) Size, dominance and copulatory success in male northern elephant seals, Mirounga angustirostris. Anim Behav 48:1249-1260

Heg D, Bachar Z, Taborsky M (2005) Cooperative breeding and group structure in the lake Tanganyika cichlid Neolamprologus savoryi. Ethology 111:1017-1043

Horrocks J, Hunte W (1983) Maternal rank and offspring rank in vervet monkeys: an appraisal of the mechanisms of rank acquisition. Anim Behav 31:772-782

Johnson CA, Grant JWA, Giraldeau L-A (2004) The effect of patch size and competitor number on aggression among foraging house sparrows. Behav Ecol 15:412-418

Johnstone RA (2011) Load lightening and negotiation over offspring care in cooperative breeders. Behav Ecol 22:436-444

Jungwirth A, Josi D, Walker J, Taborsky M (2015) Benefits of coloniality: communal defence saves anti-predator effort in cooperative breeders. Funct Ecol 29:1218-1224
Kingma SA, Santema P, Taborsky M, Komdeur J (2014) Group augmentation and the evolution of cooperation. Trends Ecol Evol 29:476484

Koenig WD, Dickinson JL (2004) Ecology and evolution of cooperative breeding in birds. Cambridge University Press, Cambridge

Koenig WD, Dickinson JL (2016) Cooperative breeding in vertebrates: studies of ecology, evolution and behavior. Cambridge University Press, Cambridge

Korsten P, Dijkstra TH, Komdeur J (2007) Is UV signalling involved in male-male territorial conflict in the blue tit (Cyanistes caeruleus)? A new experimental approach. Behaviour 144:447-470

Kraaijeveld K, Gregurke J, Hall C, Komdeur J, Mulder RA (2004) Mutual ornamentation, sexual selection, and social dominance in the black swan. Behav Ecol 15:380-389

Krause J, Ruxton GD (2002) Living in groups. Oxford University Press, Oxford

López P, Martín J (2001) Fighting rules and rival recognition reduce costs of aggression in male lizards, Podarcis hispanica. Behav Ecol Sociobiol 49:111-116

McGlothlin JW, Jawor JM, Greives TJ, Casto JM, Phillips JL, Ketterson ED (2008) Hormones and honest signals: males with larger ornaments elevate testosterone more when challenged. J Evol Biol 21: $39-48$

Midamegbe A, Grégoire A, Perret P, Doutrelant C (2011) Female-female aggressiveness is influenced by female coloration in blue tits. Anim Behav 82:245-253

Mumme RL, de Queiroz A (1985) Individual contributions to cooperative behaviour in the acorn woodpecker: effects of reproductive status, sex and group size. Behaviour 95:290-313

Murphy TG, Hernández-Muciño D, Osorio-Beristain M, Montgomerie R, Omland KE (2009) Carotenoid-based status signaling by females in the tropical streak-backed oriole. Behav Ecol 20:1000-1006

Nakagawa S, Ockendon N, Gillespie DOS, Hatchwell BJ, Burke T (2007) Assessing the function of house sparrows' bib size using a flexible meta-analysis method. Behav Ecol 18:831-840

Patten MA, Smith-Patten BD (2008) Black-crested titmouse (Baeolophus atricristatus), version 2.0. In: Poole AF (ed) The Birds of North America. Cornell Lab of Ornithology, Ithaca

Penteriani V, Delgado MM, Clavero M, Ivanc M (2015) Spottiness of European graylings (Actinopterygii, Salmonidae) correlates with environmental features and could signal the status of individuals. Ital $\mathrm{J}$ Zool 82:202-211

Pereira ME (1992) The development of dominance relations before puberty in cercopithecine societies. In: Silverberg J, Gray JP (eds) Aggression and peacefulness in humans and other primates. Oxford University Press, Oxford, pp 117-149

Pham TT, Queller PS, Tarvin KA, Murphy TG (2014) Honesty of a dynamic female aggressive status signal: baseline testosterone relates to bill color in female American goldfinches. J Avian Biol $45: 22-28$

Pravosudova EV, Grubb TC Jr, Parker PG, Doherty J, Paul F (1999) Patch size and composition of social groups in wintering tufted titmice. Auk 116:1152-1155

Pravosudova EV, Parker PG, Gaunt AS (2002) Genetic evidence for extrapair paternity in the tufted titmouse. Wilson Bull 114:279-281

Pryke SR, Andersson S (2003) Carotenoid-based status signalling in redshouldered widowbirds (Euplectes axillaris): epaulet size and redness affect captive and territorial competition. Behav Ecol Sociobiol 53:393-401

Queller PS, Murphy TG (2017) Seasonal variation in the utility of a status signaling system: plumage ornament predicts foraging success only during periods of high competition. PLoS ONE 12:e0185584

Rasband WS (1997-2018) ImageJ. U. S. National Institutes of Health. Bethesda, https://imagej.nih.gov/ij/. Accessed 12 July 2018 
R Core Team (2018). R: A language and environment for statistical computing. R Foundation for Statistical Computing, Vienna, Austria. https://www.R-project.org/.

Reichert MS, Gerhardt HC (2011) The role of body size on the outcome, escalation and duration of contests in the grey treefrog, Hyla versicolor. Anim Behav 82:1357-1366

Rémy A, Grégoire A, Perret P, Doutrelant C (2010) Mediating malemale interactions: the role of the UV blue crest coloration in blue tits. Behav Ecol Sociobiol 64:1839-1847

Richardson DS, Jury FL, Blaakmeer K, Komdeur J, Burke T (2001) Parentage assignment and extra-group paternity in a cooperative breeder: the Seychelles warbler (Acrocephalus sechellensis). Mol Ecol 10:2263-2273

Rohwer S (1975) The social significance of avian winter plumage variability. Evolution 29:593-610

Rohwer S (1977) Signaling in Harris sparrows: some experiments in deception. Behaviour 61:107-129

Scheiber IBR, Weiss BM, Frigerio D, Kotrschal K (2005) Active and passive social support in families of greylag geese (Anser anser). Behaviour 142:1535-1557

Scott DK (1980) Functional aspects of the pair bond in winter in Bewick's swans (Cygnus columbianus bewickii). Behav Ecol Sociobiol 7:323-327

Searcy WA, Nowicki S (2005) The evolution of animal communication. Princeton University Press, Princeton

Senar JC, Camerino M (1998) Status signalling and the ability to recognize dominants: an experiment with siskins (Carduelis spinus). Proc R Soc Lond B 265:1515-1520

Taborsky M (1984) Broodcare helpers in the cichlid fish Lamprologus brichardi: their costs and benefits. Anim Behav 32:1236-1252

Taborsky M (1985) Breeder-helper conflict in a ciclid fish with broodcare helpers: an experimental analysis. Behaviour 95:45-75
Temeles EJ (1994) The role of neighbours in territorial systems: when are they 'dear enemies'? Anim Behav 47:339-350

Thompson CW, Moore MC (1991) Throat colour reliably signals status in male tree lizards, Urosaurus ornatus. Anim Behav 42:745-753

Tibbetts EA, Dale J (2004) A socially enforced signal of quality in a paper wasp. Nature 432:218-222

van der Velde M, Haddrath O, Verkuil YI, Baker AJ, Piersma T (2017) New primers for molecular sex identification of waders. Wader Study 124:147-151

Vedder O, Schut E, Magrath MJL, Komdeur J (2010) Ultraviolet crown colouration affects contest outcomes among male blue tits, but only in the absence of prior encounters. Funct Ecol 24:417-425

Weatherhead PJ (1989) Nest defence by song sparrows: methodological and life history considerations. Behav Ecol Sociobiol 25:129-136

Weiss BM, Kotrschal K (2004) Effects of passive social support in juvenile Greylag geese (Anser anser): a study from fledgling to adulthood. Ethology 110:429-444

Wingfield JC, Moore IT, Goymann W, Wacker DW, Sperry T (2006) Contexts and ethology of vertebrate aggression: implications for the evolution of hormone-behavior interactions. In: Nelson RJ (ed) Biology of Aggression. Oxford University Press, Oxford, pp 179204

Wood KA, Ponting J, D'Costa N, Newth JL, Rose PE, Glazov P, Rees EC (2017) Understanding intrinsic and extrinsic drivers of aggressive behaviour in waterbird assemblages: a meta-analysis. Anim Behav 126:209-216

Publisher's note Springer Nature remains neutral with regard to jurisdictional claims in published maps and institutional affiliations. 